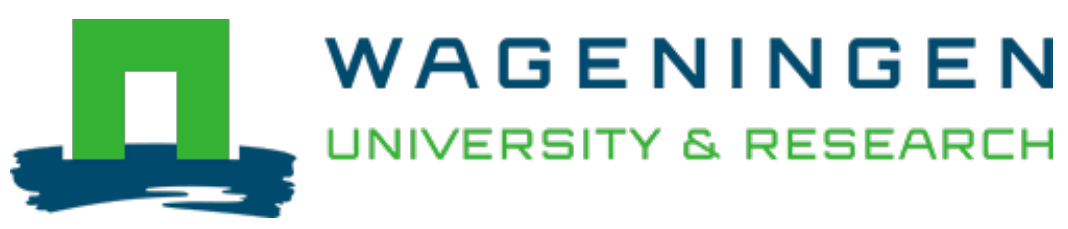

\title{
Addressing Social-Ecological Systems across Temporal and Spatial Scales : a Conceptual Synthesis for Ethnobiology
}

\author{
Human Ecology
}

Albuquerque, Ulysses Paulino; Ludwig, David; Feitosa, Ivanilda Soares; Moura, Joelson Moreno Brito; Medeiros, Patrícia Muniz et al

https://doi.org/10.1007/s10745-020-00189-7

This article is made publicly available in the institutional repository of Wageningen University and Research, under the terms of article $25 \mathrm{fa}$ of the Dutch Copyright Act, also known as the Amendment Taverne. This has been done with explicit consent by the author.

Article 25 fa states that the author of a short scientific work funded either wholly or partially by Dutch public funds is entitled to make that work publicly available for no consideration following a reasonable period of time after the work was first published, provided that clear reference is made to the source of the first publication of the work.

This publication is distributed under The Association of Universities in the Netherlands (VSNU) 'Article $25 \mathrm{fa}$ implementation' project. In this project research outputs of researchers employed by Dutch Universities that comply with the legal requirements of Article $25 \mathrm{fa}$ of the Dutch Copyright Act are distributed online and free of cost or other barriers in institutional repositories. Research outputs are distributed six months after their first online publication in the original published version and with proper attribution to the source of the original publication.

You are permitted to download and use the publication for personal purposes. All rights remain with the author(s) and / or copyright owner(s) of this work. Any use of the publication or parts of it other than authorised under article $25 \mathrm{fa}$ of the Dutch Copyright act is prohibited. Wageningen University \& Research and the author(s) of this publication shall not be held responsible or liable for any damages resulting from your (re)use of this publication.

For questions regarding the public availability of this article please contact openscience.library@,wur.nl 


\title{
Addressing Social-Ecological Systems across Temporal and Spatial Scales: a Conceptual Synthesis for Ethnobiology
}

\author{
Ulysses Paulino Albuquerque ${ }^{1}$ (D) - David Ludwig ${ }^{2}$ - Ivanilda Soares Feitosa ${ }^{1}$ - Joelson Moreno Brito de Moura ${ }^{1,3}$. \\ Patrícia Muniz de Medeiros ${ }^{4}$ - Paulo Henrique Santos Gonçalves ${ }^{1}$ - Risoneide Henriques da Silva ${ }^{1,3}$. \\ Taline Cristina da Silva ${ }^{5} \cdot$ Thiago Gonçalves-Souza $^{6} \cdot$ Washington Soares Ferreira Júnior $^{7}$
}

Accepted: 11 October 2020 / Published online: 11 November 2020

(C) Springer Science+Business Media, LLC, part of Springer Nature 2020

\begin{abstract}
We develop an integrative conceptual framework for addressing social-ecological systems across different spatial and temporal scales. Ethnobiologists study social-ecological systems through the lens of heterogeneous disciplines from the natural sciences, social sciences, and humanities. Despite the integrative ambitions of the field, ethnobiology often remains fragmented through research programs that emphasize different methods and scales. We propose a conceptual synthesis of three processes: (1) cognitive processing, (2) cultural transmission, and (3) biocultural evolution. We also discuss how social negotiation is embedded in them. By showing how these different processes interact across different spatial and temporal scales, we develop a framework for ethnobiological scholarship that can address complex dynamics in social-ecological systems.
\end{abstract}

Keywords Ethnobiology $\cdot$ Natural sciences $\cdot$ Social science $\cdot$ Humanities $\cdot$ Cognitive processing $\cdot$ Cultural transmission . Biocultural evolution $\cdot$ Knowledge integration $\cdot$ Social-ecological systems

\section{Introduction}

Human interactions with biota in social-ecological systems are inherently complex and develop along different spatial and temporal scales. Ethnobiology has emerged as a multidisciplinary field that studies complex dynamics in socialecological systems through heterogeneous disciplines from ecology and evolution to cognitive psychology and linguistics to cultural and environmental anthropology to Indigenous studies and political ecology. A more classic definition would

Ivanilda Soares Feitosa deceased.

Ulysses Paulino Albuquerque upa677@hotmail.com

1 Laboratório de Ecologia e Evolução de Sistemas Socioecológicos (LEA), Departamento de Botânica, Universidade Federal de Pernambuco, Av. Prof. Moraes Rego, 1235, Cidade Universitária, Recife, Pernambuco 50670-901, Brazil

2 Knowledge Technology and Innovation (KTI) Group, Wageningen University and Research, Wageningen, Netherlands

3 Programa de Pós-graduação em Etnobiologia e Conservação da Natureza, Departamento de Biologia, Universidade Federal Rural de Pernambuco, Rua Dom Manoel de Medeiros, s/n, Dois Irmãos, PE 52171900, Brazil be the study of the direct interrelations between people and biota, including the fields such as ethnobotany, ethnozoology, ethnoecology, and ethnomycology.

Ethnobiologists widely embrace an integrative identity of their field and ethnobiology has been hailed "as the interdiscipline with the greatest explanatory power in helping society understand biocultural complexity" (Nabhan 2016: 11). Along similar lines, Wolverton (2013) argued that "ethnobiology is well-suited to serve as an interdisciplinary umbrella for environmental scientists, conservation biologists,

4 Laboratório de Ecologia, Conservação Evolução Biocultural, Campus de Engenharias e Ciências Agrárias, Universidade Federal de Alagoas, BR 104 s/n, Mata do Rolo, Rio Largo, Alagoas 57100000, Brazil

5 Laboratório de Etnobiologia e Conservação de Ecossistemas, Universidade Estadual de Alagoas, Palmeira dos Índios, Al 57604-597, Brazil

6 Laboratório de Síntese Ecológica e Conservação da Biodiversidade, Departamento de Biologia, Universidade Federal Rural de Pernambuco, Dois Irmãos, Recife, Pernambuco, Brazil

7 Laboratório de Investigações Bioculturais no Semiárido, Universidade de Pernambuco, Campus Petrolina, Rodovia BR 203, Km 2, s/n - Vila Eduardo, Petrolina, PE 56328-903, Brazil 
restoration ecologists, environmental philosophers, and others who engage in applied research related to human-environment interactions." "Ethnobiology 5" (Wyndham et al. 2011; Wolverton 2013) has emerged as a label for these ambitions to provide an integrative framework for the study of socialecological systems. Reflecting on Hunn's (2007) periodization of the field into four phases, ethnobiology 5 brings together the intellectual resources of earlier phases with applied concerns about social-ecological change at local and global scales. The prior four phases concern the advances of ethnobiological approaches, since its formal beginning with the concept of ethnobotany in 1895, before reaching cognitive ethnobiology (phase 2), characterized by studies documenting indigenous knowledge from an emic perspective. It also achieved a higher ecological focus - ethnoecology (phase 3:) before reaching a focus on understanding the intellectual property rights of indigenous peoples and local communities (phase 4) (Hunn 2007).

However, as Ludwig (2018) argued, these inter- and transdisciplinary promises of programmatic articles do not match the often-fragmented multidisciplinary reality of the field. Indeed, ethnobiology provides space for researchers with heterogeneous training in the natural sciences, social sciences, and humanities. At the same time, these researchers often employ concepts and methods that remain disconnected. Therefore, the diversity of academic formations and approaches, which should undoubtedly become an advantage of the field, sometimes leads to the establishment of clusters in terms of interests and world views, which often compromises the dialogue among ethnobiologists or between ethnobiologists and scientists in other disciplines. Therefore, ethnobiology does not currently provide an integrative framework that guides scholars in other fields. In fact, ethnobiological scholarship often remains underrepresented or even invisible in wider interdisciplinary debates about issues such as inclusive development, human ecology, sustainability, resilience, and the utility of trans-disciplinary approaches.

Another issue that permeates ethnobiology is that basic and applied studies are often seen as competing or unassociated. As most theory-driven and hypothesis-testing studies are developed under the "basic" label, applied studies are often viewed as contributing little to scientific development. On the other hand, the basic approach is often criticized for not matching the needs of local communities. Therefore, we believe that a more integrative practice in ethnobiology could help to approximate basic and applied research.

Here we aim to contribute to this more integrative practice in ethnobiology through a conceptual synthesis of research in different areas of the field. We depart from the recognition that ethnobiological scholarship engages with different spatial scales from the individual to the macrosystem level and with different temporal scales along intra- and intergenerational dimensions. As a second step, we identify three general processes (cognitive processing, cultural transmission, and biocultural evolution) and address their interaction across scales. Finally, we discuss how social negotiation is embedded in these general processes. Social negotiation should not be seen here as a discipline or academic approach, but rather as a dialoguing strategy among different social actors.

\section{Towards a Synthesis in Ethnobiology}

We propose a synthesis for relating different domains of ethnobiological research that address fundamental processes along different temporal and spatial scales. We take inspiration from integrative frameworks in other fields, such as population genetics and community ecology. In population genetics, the four fundamental processes are mutation, gene flow (migration), genetic drift, and natural selection. Likewise, the conceptual synthesis in community ecology recognizes four processes: speciation, dispersal, ecological drift, and selection (Vellend 2010, 2020). In general terms, the fundamental processes of these two disciplines represent (i) the origin of new types (genes or species), (ii) the movement (of individuals) across space, (iii) a stochastic component adding or removing individuals from one time to another, and (iv) selection (Vellend 2020). In ethnobiology, we suggest three general processes: cognitive processing, cultural transmission, and biocultural evolution.

Cognitive processing refers to resources of individuals and communities to store and recover information about the environment through classification, memory, perception, and decision making. Cultural transmission is a process that entails copying and sharing information among individuals. Biocultural evolution is a process where changes caused by humans to the environment have an influence on the evolution of other organisms, but this effect also has a feedback loop determining the evolution of humans.

Certainly, it is possible to link some of the fundamental processes of ecology and genetics (dispersal or migration, speciation or mutation, and selection) with the proposed processes of ethnobiology. For example, cognitive processing might steady a cultural innovation in one population if this innovation is beneficial, which is analogous to speciation (ecology) or mutation (genetics). In addition, this innovation could spread to other populations (cultural transmission) when some individuals disperse or migrate to new areas, which is similar to the dispersal processes of ecology and genetics, increasing the amount of information in the systems (e.g., novel medicinal species). Finally, certain resources can offer people greater adaptive advantages. These resources may increase in popularity (and cultural importance) over time, decreasing the popularity or excluding resources that offer fewer advantages. This can negatively affect the richness of known species over time in a human group. Such processes, which are included in the scope of biocultural evolution, may correspond to the selection processes in ecology and population genetics. 
Here, we propose a conceptual synthesis for ethnobiology that explicitly considers the three general processes mentioned that can underlie the relationships between humans and nature at multiple spatial and temporal scales in social-ecological systems. The proposed synthesis was motivated by previous syntheses in ecology and evolution (Johnson and Stinchcombe 2007; Vellend 2010), but also by provocative studies in ethnobiology (Wyndham et al. 2011; Wolverton 2013; Ludwig 2018). We first present the scale problem in ethnobiology to demonstrate the need for more studies at different spatial and temporal scales and how our proposal for conceptual synthesis considers the fundamental processes in ethnobiology at these scales. Then, we represent the theoretical aspects of each general process and provide some practical examples of studies in each of them. We also provide some follow-up questions that illustrate our approach, which might also stimulate future studies in ethnobiology. Finally, we discuss how these processes are related to the topic of social negotiation.

\section{The Issue of Scale in Ethnobiology}

To understand social-ecological systems, a key entity in ethnobiology, it is necessary to consider different spatial and temporal scales. For that, it is necessary to carry out interdisciplinary research that brings together different fields, from ecology and evolution to psychology and linguistics to anthropology and sociology, that have produced investigations at different scales (for ecology and evolution studies, see Roy et al. 1996; Haloin and Strauss 2008). Particularly for ethnobiology, most studies have been carried out at the local (community) scale (Albuquerque and Alves 2016) and relatively few have investigated different communities in a region (local metacommunities) (for example, Reyes-García et al. 2013; Silva et al. 2016) or groups living in different regions of the planet (macrosystems) (see Saslis-Lagoudakis et al. 2012; Gonçalves et al. 2016; Santoro et al. 2017) (Table 1, Fig. 1).

Table 1 Explanations of some important terms for a conceptual synthesis in ethnobiology

\section{Important terms}

Processes

General processes

\section{Definition}

Processes that affect patterns linked to the structure, dynamics, and evolution of social-ecological systems; cognitive processing, cultural transmission and biocultural evolution
Spatial scale

Specific processes

Individual

Local community

Local metacommunities

Macrosystem

Temporal scale

Intragenerational

Intergenerational

Fitness

Biological

Cultural
Contingent factors that contribute to changes in general processes.

Smaller spatial scale for investigating processes in ethnobiology, representing each of those who are part of a social-ecological system. At this scale, it is possible to investigate how cognitive processing contributes to the retention of information about the environment, in addition to verifying the individual biases that affect the transmission of this information.

Scale involving a human group and interactions with its environment. Studies at this scale, for example, can verify how general processes affect the cultural importance of certain resources to the detriment of others in the group.

A set of distinct human groups living in a region where they can interact with each other. Studies that consider this spatial scale, for example, can investigate the similarity of knowledge about useful species between these groups and how general processes (e.g., cognitive processing) determine this resemblance.

A larger spatial scale covering systems living in different regions with limited or prevented contact between groups. Studies with these larger scales can inform patterns of social-ecological systems at a global level, for example.

Scale involving studies that investigate processes in a punctual manner or that follow the communities studied in the short term, in a generation.

Research on processes in social-ecological systems over two or more generations that uses large temporal investigations or use analytical tools to evaluate evolutionary patterns of human populations.

Relative to biological (reproductive) success.

Relative to cultural success of information and/or behavior at an individual or societal scale. 
Despite the great importance of local studies, going beyond the focus on small spatial scales (local community) is a necessary investment of ethnobiological investigations, which might look at broader spatial or temporal scales to better understand processes shaping social-ecological systems. For example, there is evidence indicating that actions at the individual (small spatial scale) level can affect general processes at a broader spatial scale. The individual processes linked to gaining different types of knowledge (such as traditional and non-traditional) can contribute to a decrease of traditional knowledge at the level of the local community over time when individuals acquire more information external to the system (non-traditional knowledge) in response to socioeconomic and environmental changes (Reyes-García et al. 2013). In addition, human-driven environmental changes can affect even broad spatial scales (regional and global), as in the case of the ongoing global climate crisis where humans are promoting the rearrangement of social-ecological systems across the planet (Pincetl 2017; Fedele et al. 2019). Recent research has also shown that interactions between different communities in a region at a broad spatial scale can interfere with individuals' decisions related to cooperation and competition in resource collection within local communities (small spatial scale) (Berkes 2010; Waring et al. 2015). Therefore, a general process acting on a certain scale can cascade up or down across different spatial or temporal scales.

Ethnobiological studies that consider the time scale are even rarer (for example, Reyes-García et al. 2013; Nascimento et al. 2018). One of the characteristics present in social-ecological systems that can be investigated over time involves feedback loops. Human actions in the environment, such as landscape management, can modify functions and processes in the ecological system, which, in turn, can affect human knowledge and behavior (Chen et al. 2017). For example, some studies have shown that high pressure on preferred species (for food, medicine, etc.) by past generations might force later generations to change resource use by selecting less preferred but more available species (see Spainer and Lavalli 2007; Rao et al. 2010). This example reinforces theoretical expectations that sociocultural and ecological systems influence each other over time, so that actions taken in the environment by earlier generations affect the environmental decisions of later generations.

Previous studies have argued that human actions in the environment can produce environmental legacies that are maintained over the long term. Human management of species in the past might favor changes that are maintained in the landscape. In the Amazon, past management practices modified current forest landscapes, so that species domesticated in the past currently have high abundance compared to nondomesticated species (Levis et al. 2017).

A theoretical example of how different scales can be incorporated in ethnobiology is the Social-Ecological Theory of
Maximization proposed by Albuquerque et al. (2019b), which explains that social-ecological systems are built to favor the survival of human beings in their interactions with different environments over different spatial and temporal scales. In this case, a set of human cognitive and behavioral mechanisms influence the construction of these systems to maximize benefits and minimize costs in interactions with the environment (ibid.). In one model, the Model of Maximum Environmental Performance, they postulate that the incorporation and differential use of resources in social-ecological systems are directed toward resources that offer the maximum return within the various parameters that influence the selection process (ibid.). The model can be evaluated at different spatial scales. For example, at the small spatial scale (a local community), an investigation of how cognitive processing (e.g., organoleptic properties, local availability, and efficiency) can determine resource selection (e.g., incorporation and differential use). Additionally, at a broad spatial scale, it is possible to consider other determinants dictating the selection of resources that are affected by three general process, such as climate. For example, in macrosystems a preference for perennial resources in human groups living in markedly seasonal environments has been observed in different semi-arid regions of the planet (in northeastern Brazil, see Albuquerque 2006; in Morocco, see Linstädter et al. 2013). This means that general processes affecting the selection of resources work at different spatial scales. Therefore, the climate of a region (broad spatial scale) influences local preferences for certain resources of a local community (small spatial scale).

Given the importance of spatial and temporal scales for the study of social-ecological systems, to the best of our knowledge, there are no syntheses organizing ethnobiological studies at different scales. We present a synthesis based on three general processes in social-ecological systems (cognitive processing, cultural transmission, and biocultural evolution) based on interdisciplinary dialogue with ecological and evolutionary scenarios (see Albuquerque and Ferreira Júnior 2017). We organized the relative importance of these general processes across different spatial and temporal scales. We argue that our proposal allows different approaches in ethnobiology to be related so that their contributions at different levels and scales within the field become clear.

The three general processes can be evaluated at different spatial and temporal scales, but their relative importance varies with scale (Fig. 1). The basic process linked to cognitive processing can range from the individual to macrosystems on the spatial scale, but it can generally operate over a short time period of just one generation (Fig. 1 first rounded circle: left). However, although processes of cultural transmission and biocultural evolution can be observed at different spatial scales, they are mainly composed of evolutionary processes that need different generations to be observed. Furthermore, the three processes do not occur in isolation and can influence 
each other over time and space (Fig. 1; see also Fig. 2). For instance, although cognition and memory are dominant at the intragenerational scale but spatially widespread, these processes can be accumulated in different metacommunities and macrosystems, which, in turn, may impact a new generation and affect cultural transmission and biocultural evolution processes. Note that social negotiation is not a process but rather a way of communicating with different actors. We further elaborate on this below.

\section{General Processes}

Cognitive processing includes gaining and understanding both the innate and cultural aspects of knowledge (information). Ludwig (2018) argued that it often remains unclear how ethnobiological scholarship relates to earlier phases of ethnobiological research that have approached local knowledge through fields such as cognitive psychology and linguistic anthropology. This general process includes the specific processes of (i) classification, (ii) perception, (iii) memory, (iv) decision making, (v) knowledge and use, and (vi) knowledge construction in new environments (Table 2, Fig. 2).

By classifying the environment, human groups can develop strategies that favor their survival, such as recognizing potential fishing areas and identifying patterns of fish migration (see Braga et al. 2019). Human classification of the natural world emerges from general cognitive and specific folk biological forms of reasoning that are shaped by cultural learning and utilitarian factors (Berlin 1992; López et al. 1997). It has become widely recognized that local classificatory systems do not only reflect local forms of cognitive processing but also the expertise of communities regarding biota and environments (Nabhan 2016).

Perception is a vital portion of cognitive processing, since the way people perceive nature has a direct impact on their behaviors and decisions (Rangel-Landa et al. 2016). For example, responsibility diffusion is common in local communities when people do not feel that their actions lead to environmental changes but rather perceive changes as a product of other people's behaviors (Gonçalves et al. 2019). In such cases, engagement in co-management strategies may be more challenging than in situations where people perceive their actions as directly connected to environmental changes. The way people perceive specific resources may also influence their current knowledge and use. For example, a group of plants known as famine foods is often consumed in situations of scarcity when other edible products are not available. Because they are associated with poverty and moments of difficulty, people often feel ashamed to reveal their knowledge of such plants, which compromises their actual use and blocks cultural transmission (Guinand and Lemessa 2001; Nascimento et al. 2012).

Memory is often neglected in ethnobiological studies, but it plays a significant role in how people interact with nature. Studies in the scope of evolutionary psychology have suggested that people preferentially store adaptive information related to their survival and reproduction (Nairne et al. 2007; Nairne and Pandeirada 2008). Such a pattern may shape, for example, the composition of local pharmacopeias and a society's most valued plants.

How memory influences local ecological knowledge at the individual level is also of relevance to ethnobiology as it may impact biological and cultural fitness. Several studies that

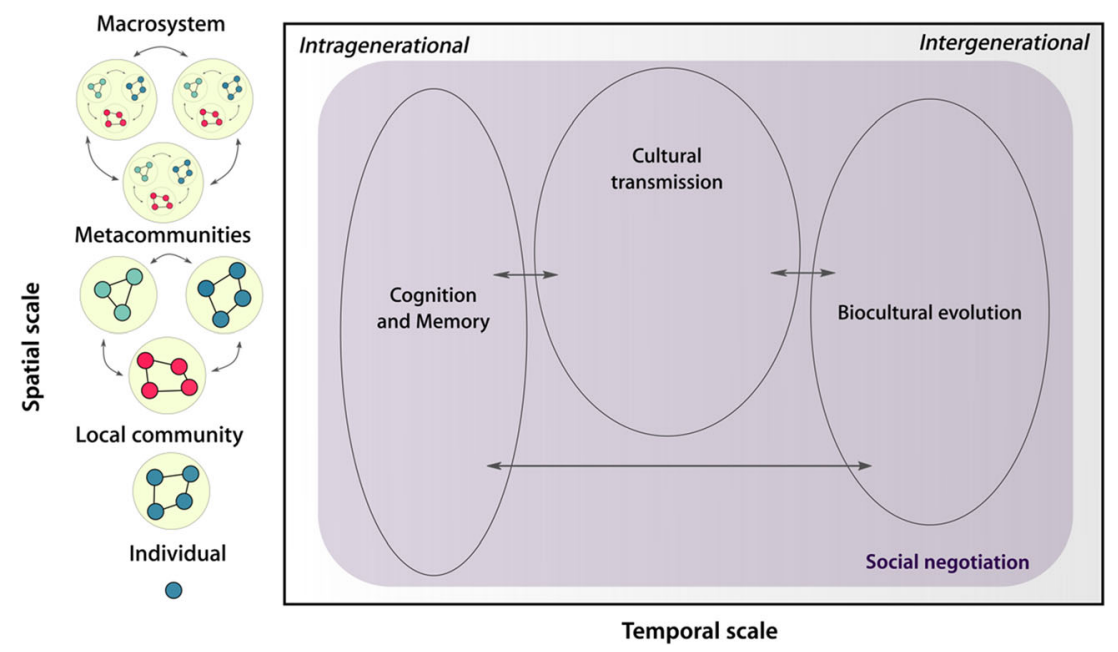

Fig. 1 Proposed conceptual synthesis of ethnobiology. We consider three general processes and their relationships that operate in social-ecological systems (cognitive processing, cultural transmission, and biocultural evolution) at different spatial and temporal scales. The gradient in light gray represents an increase in the temporal scale from intragenerational to intergenerational (x-axis). Conversely, the dark-shaded area demonstrates the social negotiation that is embedded in the three general processes. The arrows connecting the three general processes describe the reciprocal influence between them that occur over different temporal and spatial scales. The long, rounded circles correspond to the spatial or temporal scale for which each process is prominent 
Fig. 2 Schematic diagram showing the nested structure of specific processes that are typically contingent but useful when aggregated in general processes. General processes represent the drivers of the variation in cultural and biological fitness

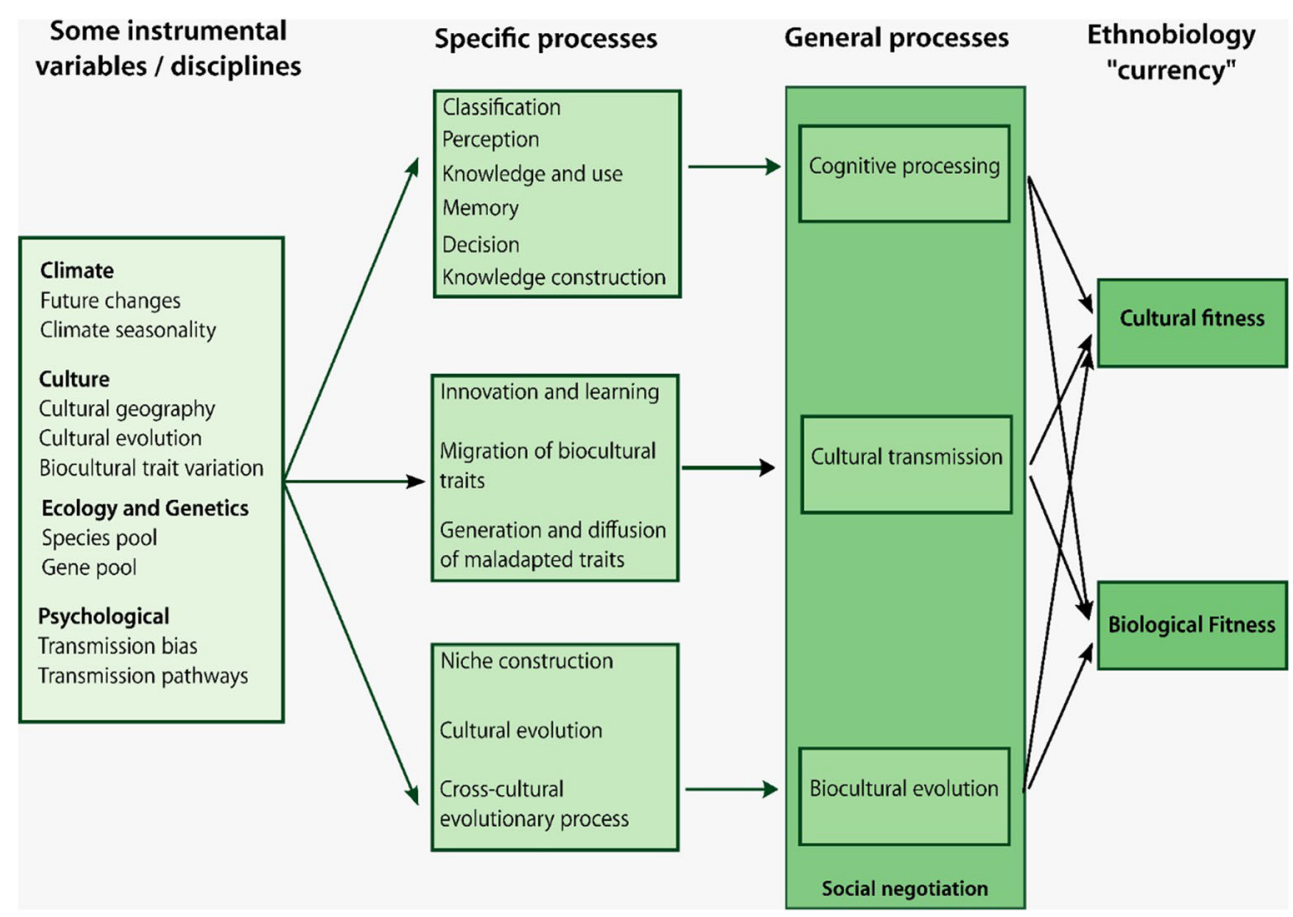

associate age and local ecological knowledge have found a common pattern in which knowledge reaches its peak among middle-aged adults and is maintained or decreases for as they age (Reyes-García et al. 2005; Ayantunde et al. 2008; Koster et al. 2016; Brito et al. 2017). This may be related to greater difficulty in storing new information after a certain age and may directly influence, for example, the ways elders incorporate recently introduced plants into their routines.

Decision making is directly linked to landscape changes and management strategies, usually addressed in agroecosystems (Bellon 2014) and plant management studies (Rangel-Landa et al. 2016). Decision making may take place at the individual level (e.g., an individual's decisions when searching for the best or most abundant resources available in the environment) (Medeiros et al. 2011), community level (e.g., when communal decisions are made concerning land use for agricultural purposes) (Bellon 2014), or outside the community, such as at the metacommunity level, when decisions may involve social negotiations among different stakeholders (Table 3) (Spalding 2020).

Ethnobiological research focuses in particular on the study of knowledge and resource use. Many of these studies report that knowledge is not evenly distributed among individuals (Hanazaki et al. 2000; Miranda and Hanazaki 2008; ReyesGarcia et al. 2010; Paniagua-Zambrana et al. 2014; N'Danikou et al. 2015; Díaz-Reviriego et al. 2016; Poderoso et al. 2017; Maua et al. 2018) (see below). For example, women often have more knowledge about cultivated medicinal plants as they tend to be responsible for preparing these resources (see Hanazaki et al. 2000), while men often know more about wild medicinal plants (Ruddle 2000;
Kujawska and Luczaj 2015). However, there currently is mixed evidence regarding the generalities of this association of knowledge with degree of engagement with a resource (Torres-Avilez et al. 2016). In fact, we argue that as a general process, cognitive processing has a prominent role in influencing knowledge that is independent of scale. Conversely, specific attributes, such as sex, might be less or more important depending on location or scale, highlighting how contingent some specific processes are despite being central to understanding biological and cultural fitness variation.

Factors such as age (Koster et al. 2016; Brito et al. 2017), education level (Giovannini et al. 2011), urbanization (Ávila et al. 2017), distance from urban areas (Vandebroek et al. 2004; Tangjitman et al. 2013), and migration (Miranda and Hanazaki 2008; Medeiros et al. 2012) can also generate differences in knowledge. For example, Giovannini et al.'s (2011) study of the influence of the variables gender, age, and education on local knowledge of medicinal plants among indigenous communities in Mexico found that schooling and age showed positive correlations with extent of knowledge of the properties and uses of these plants.

That human knowledge constantly adapts to changing circumstances is fundamental to the resilience of socialecological systems (Díaz-Reviriego et al. 2016). There are two basic processes to form individual or group knowledge repertoires: the production of knowledge and the transmission of this information (Cavalli-Sforza and Feldman 1981; Mesoudi et al. 2006). These processes are not random as they vary in response to environmental and social factors (Boyd and Richerson 2005). The adaptive capacity of systems allows individuals and groups to adjust to changes in their 


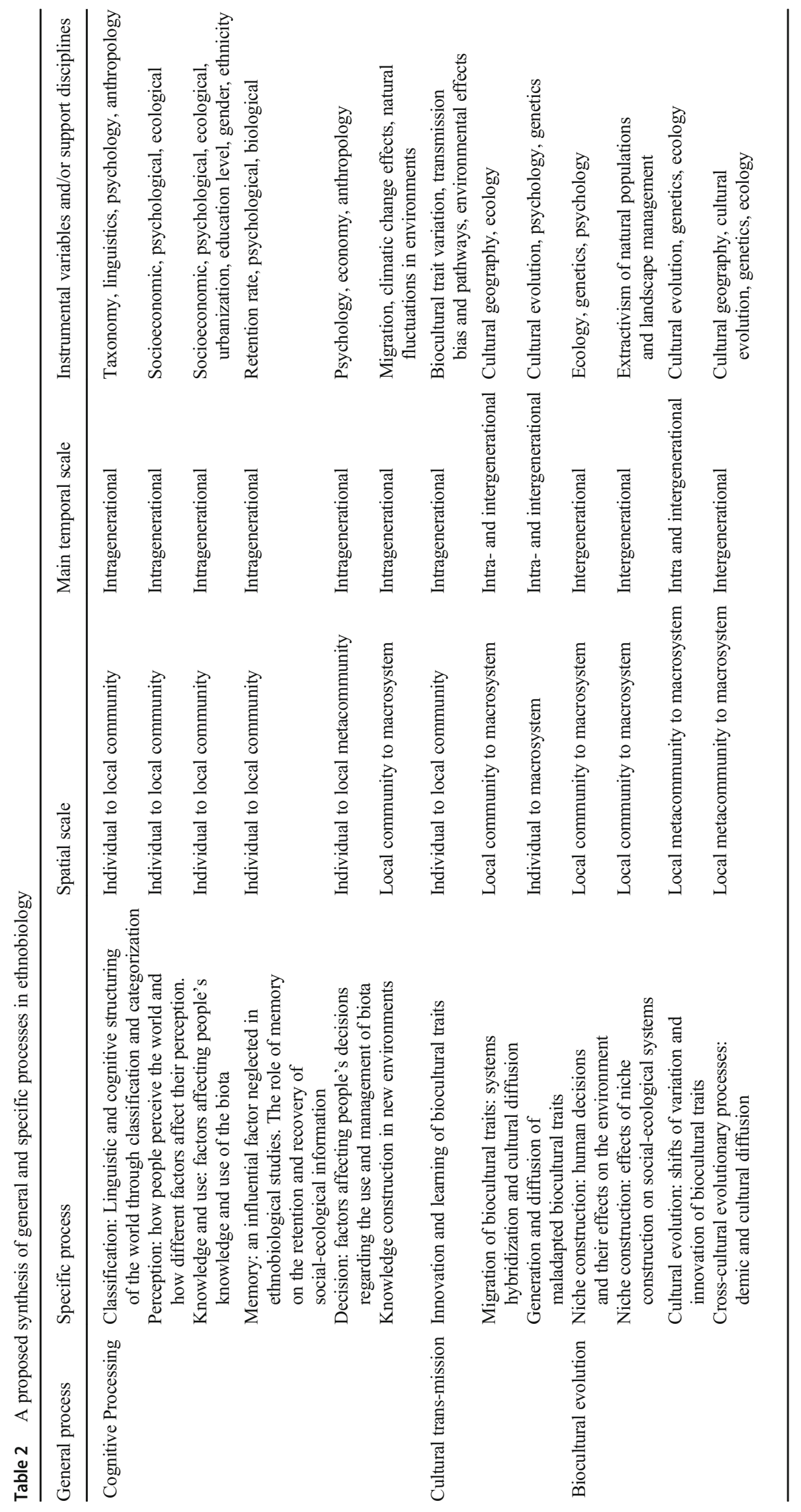


Table 3 Social negotiation as "transversal strategy" in our proposal

\begin{tabular}{|c|c|c|c|c|}
\hline & Approach & Spatial scale & $\begin{array}{l}\text { Main temporal } \\
\text { scale }\end{array}$ & Support disciplines \\
\hline \multirow[t]{3}{*}{$\begin{array}{l}\text { Social } \\
\text { Negotiation }\end{array}$} & $\begin{array}{c}\text { Management practices: negotiation } \\
\text { of agricultural, conservation, } \\
\text { hunting, medical, etc. practices }\end{array}$ & $\begin{array}{l}\text { Local community to } \\
\text { macrosystem }\end{array}$ & Intragenerational & $\begin{array}{l}\text { Agriculture and agroecology, } \\
\text { conservation biology, } \\
\text { human ecology, } \\
\text { sustainability studies }\end{array}$ \\
\hline & $\begin{array}{l}\text { Policy: negotiation of framework } \\
\text { for addressing management } \\
\text { practices }\end{array}$ & $\begin{array}{l}\text { Local community to } \\
\text { macrosystem }\end{array}$ & Intragenerational & $\begin{array}{l}\text { Research and innovation policy, } \\
\text { conservation governance, } \\
\text { transdisciplinary design }\end{array}$ \\
\hline & $\begin{array}{l}\text { Political contestation: identifying } \\
\text { and challenging inequity and } \\
\text { marginalization in management } \\
\text { practices and policy frameworks }\end{array}$ & $\begin{array}{l}\text { Local community to } \\
\text { macrosystem }\end{array}$ & Intragenerational & $\begin{array}{l}\text { Political ecology, political } \\
\text { epistemology, Indigenous } \\
\text { studies, } \\
\text { decolonial theory }\end{array}$ \\
\hline
\end{tabular}

environment, including human-driven disturbances that lead to a decrease in available resources or the introduction of previously unknown diseases (Ladio and Lozada 2008; Díaz-Reviriego et al. 2016) .

Cultural transmission is the process of production, copying, and sharing of information among individuals (ReyesGarcía et al. 2009; Mesoudi 2015; Salpeteur et al. 2015), including specific processes that have been widely studied in ethnobiology; (i) innovation and learning of biocultural traits, (ii) migration of biocultural traits, and (iii) generation and diffusion of maladapted cultural traits (see Dantas et al. 2020) (Table 2, Fig. 2).

Previous studies have indicated that biases occur during the process of cultural transmission (see Heath et al. 2001; Barrett and Broesch 2012; Eriksson and Coultas 2014) that can affect contingent patterns for local populations facing different environmental pressures or diseases outbreaks. In addition, the specific processes might exhibit distinct effects depending on the spatial or temporal scales studied (see Santoro et al. 2020).

Cultural transmission interacts with cognitive processing (see Nairne et al. 2007; Eyssartier et al. 2008; Santoro et al. 2018; Brito et al. 2019). For example, people both easily remember and readily share their experience of contaminated foods (Eriksson and Coultas 2014), or a disease outbreak could trigger social learning about medicinal plants which, in turn, increases the likelihood of local populations' survival (Soldati et al. 2015). However, we need to understand how factors occurring at individual levels can scale up shaping cultural transmission.

Some biases of the content of information are cultural traits most likely to be transmitted (Mesoudi 2016). For example, Henrich and Henrich (2010) found that information regarding food taboos for toxic marine species tended to be faster learned and transmitted by pregnant and lactating women than information about other species. As a result, content bias may act on knowledge learning and transmission (ibid.).

As human memory tends to privilege information that contributes to survival chances (see Nairne et al. 2007; Nairne and
Pandeirada 2008), it has the greatest likelihood of being copied and shared. Therefore, memory biases that favor adaptive information may be intrinsically linked to the process of cultural transmission as it affects both biological and cultural fitness.

People's environmental circumstances can also determine how information is copied and differentially shared (context bias) (Soldati et al. 2015; Santoro et al. 2018). For example, when there are no public policies for controlling malaria the incidence of the disease in areas of Africa interferes with the use of antimalarial medicinal plants (Santoro et al. 2017). The recurrence of such a risk event is likely to be an important factor altering the information surrounding medicinal plants that will be preferentially copied and transmitted by people, which, in turn, is relevant information that can have an adaptive role in dealing with the environmental challenge.

Another bias active in the process of cultural transmission in social-ecological systems that can occur from the individual to community level is related to the "temporal lags" in transmission. Previous studies suggest there are differences between the knowledge of older and younger people due to intergenerational baselines (Hanazaki et al. 2013; Bender et al. 2014; Fernández-Llamazares et al. 2015). This dynamic reference syndrome can occur in a human group when the following conditions are met: (1) relevant environmental changes due to disturbances that affect, for example, the availability of resources; (2) lack of communication between generations, which limits the transmission of information regarding previous environmental states to younger generations; (3) differences between generations regarding perceptions of environmental changes (Fernández-Llamazares et al. 2015).

The process of cultural transmission can also be biased by a complete lack of intragenerational communication, although this has been little studied and evidenced in ethnobiology. Environmental changes associated with a lack of intergenerational communication can affect the capacity of individuals and populations to deal with rapid changes and, consequently, influence the resilience of the social-ecological system. This 
change occurs because with each new generation, previous environmental changes and their causes are less and less apparent. In this case, younger generations can assume that certain species are naturally scarce or abundant in their environment, possibly leading to, for example, the unsustainable use of some species. Therefore, an awareness of the basic processes that occur at the individual level is extremely important for understanding the complexity of social-ecological systems and provides a broad perspective of the interactions among different levels of the system, identifying, for example, points of convergence between them.

Biocultural evolution involves a process of reciprocal causation between human groups and their environments, so that cultural practices can affect properties of the environment and, in turn, human-driven or natural changes can lead to the selection of certain biocultural traits over time. This general process comprises different specific processes; (i) niche construction, (ii) cultural evolution, and (iii) cross-cultural evolutionary processes (Table 2, Fig. 2).

Human agricultural practices that emerged some 12,000 years ago entailed new selective pressures that impacted the evolutionary history of our species and others (Altman and Mesoudi 2019). Human beings, like other organisms, can modify their environment to suit their needs, influencing their own evolution or that of other organisms, a process referred to as niche construction (Laland and Brown 2006; Albuquerque et al. 2015, 2018; Albuquerque et al. 2019a, 2019b). Among humans, the processes of niche construction are distinct since they are influenced by learning processes and are culturally transmitted (Albuquerque et al. 2019a, 2019b).

Ethnobotanical studies at the local community (Monteiro et al. 2011) and metacommunity levels (Bufford and Gaoue 2015; Feitosa et al. 2017; Amahowe et al. 2018; Gaoue et al. 2019) (Fig. 1) show how human management and extraction practices can alter the strategies of certain plant species. Gaoue et al. (2019) analyzed how human harvesting and environmental stressors (e.g., drought) can influence the responses of the plant species Khaya senegalensis in two regions of West Africa with contrasting climates (dry vs. wet). They argue that frequent harvesting of biomass acts as a selective pressure on plants mediated by climate. Harvesting in the dry region favored a rapid transition of plant reproductive stages, which, in turn, buffered the negative effect of drought decreasing plant mortality. Their results illustrate the relevance of integrating spatially heterogeneous data, because locally focused information may fail to detect different strategies of the same species.

Another recent study demonstrated that pre-Columbian societies determined present-day patterns of plant species composition by domesticating preferred plant species (Levis et al. 2017). Their resource use may have altered vegetation structure on a large scale over time, and the study notes that about $1.5 \%$ of tree species in the Amazon forest represent half of all individual trees found in different areas of the forest (ibid.). Some of these trees are at different stages of domestication; incipient, semi-domesticated, or domesticated, as a result of pre-Columbian management practices (ibid.).

In the Araripe National Forest in northeastern Brazil, Silva et al. (2017) studied the effects of human actions on landscape domestication based on biological evidence and the perceptions of local populations. In this case, landscape management in the past favored the development of heliophile species useful for contemporary communities. However, with the creation of a conservation area in the region, communities were removed from the interior of the forest and the process of natural regeneration increased the forest cover to favor abundant ombrophilous species over the species used by people (ibid.) (for a more complete treatment of the niche construction process, see Albuquerque et al. 2019a, 2019b).

The ways cultural practices cause environmental changes and influence the relationship between humans and nature can also be analyzed from a macrosystem perspective (Figs. 1 and 2). Santoro et al. (2017), for example, analyzed whether local medical systems respond to environmental changes mediated by humans in their role as niche builders. They suggested that in highly deforested places with a higher incidence of malaria, there would be an adaptive response from local populations that would reflect a greater wealth of medicinal plants used to treat malaria. Moreover, populations that historically dealt with malaria but that currently have a low incidence of the disease may have a richer pharmacopeia for the treatment of malaria compared to populations that currently have a high incidence but no previous experience of treatments or transmission of malaria (ibid.). Therefore, the complexity of people-environment interactions can be understood more broadly if the experimental designs of ethnobiological studies aim to incorporate both inherent genetic and cultural aspects of this relationship (Moura et al. 2020).

In general, a macrosystem comprises larger spatial and temporal scales (Fig. 1). Although each local community has its own cultural system that affects its relationship with its environment, there are some emergent properties of these interactions that tend to occur in regional patterns (Albuquerque and de Medeiros 2012; Gutiérrez-Santillán et al. 2019). Hypotheses and theories regarding the organization patterns of social-ecological systems need to be generated to identify these patterns. In fact, whereas specific processes may be contingent in different local communities, general processes encapsulate those emergent properties. A new approach termed macroethnobiology (ibid.) may be useful in generating large scale strategies for conservation and bioprospecting (Albuquerque and de Medeiros 2012).

Most ethnobiological studies focus on use patterns of medicinal plants on regional and global scales. Macroethnobiology addresses spatial patterns in taxonomic and phylogenetic structures of traditional pharmacopoeias. By using statistical 
approaches comparing traditional pharmacopeias with the regional flora, species from the families Rosaceae, Asteraceae, and Lamiaceae were found to be over-represented in traditional pharmacopoeias, while the families Poaceae, Orchidaceae, and Bromeliaceae were under-represented (Moerman 1991; Moerman 1979; Weckerle et al. 2011; Medeiros et al. 2013). A global test has also demonstrated that the selection of medicinal or crop plant species and livestock animals is not random and can be guided by phylogenetic relationships (Milla et al. 2018).

Other studies have focused on a broader geographical scale to test whether these patterns persist in pharmacopoeias of very different cultures (comparing the medicinal flora of Nepal, New Zealand, and the Cape of South Africa) (SaslisLagoudakis et al. Saslis-Lagoudakis et al. 2011, SaslisLagoudakis et al. 2012). Despite the considerable cultural differences, there are some phylogenetic lineages that are highly valued in all these traditional pharmacopoeias, including the botanical families of Lamiaceae, Malvaceae, Rubiaceae, and Solanaceae (ibid.). Therefore, there is a cross-cultural phylogenetic conservatism in the selection of medicinal plants guided by a phylogenetic conservatism in phytochemistry. Moreover, this convergent medicinal use of the same species is a strong indication of their biochemical efficacy. These and similar ethnobotanical findings are beginning to be used in bioprospecting. For example, most of the plant species of the Fabaceae family cited with records of medicinal use in the ethnobiological literature have been subjected to ethnopharmacological screening (Souza et al. 2018).

Another approach is the study of phenomena affecting the inclusion of introduced plant species in traditional pharmacopoeias. Hart et al. (2017) compared the indigenous use of medicinal plants before Spanish colonization and current data in several local communities in Ecuador and found that introduced plants were over-represented in the traditional pharmacopoeias, although they are not as frequently used to treat diseases that appeared after Spanish colonization. Hart et al. proposed three different explanations for this finding; a) the ingress of these plants in the Ecuadorian pharmacopeia happened well after the Spanish conquest, thus, they could not be used to treat endemic diseases, at least initially; b) because of social disruption and epidemics during and after the Spanish conquest, Indigenous communities were unable to experiment with introduced plants; and c) post-contact diseases may be perceived as more severe, thus, Indigenous communities would prefer to use native species that they knew and trusted (ibid.).

The eco-evolutionary dynamics arising from the relationship between human beings and their environment can be studied at a large temporal scale. For example, McGraw (2001) tested the effect of high extractive pressure on the morphological traits of the medicinal plant Panax quinquefolius, examining specimens from 17 herbariums from four regions of Canada collected from areas of high vs. low extractive pressure. He observed a decline in the size of morphometric traits in areas of high extraction. It is likely that human harvesting of larger plants (probably due to their high economic return) has driven natural selection and, consequently, microevolution for these species (ibid.). On a larger temporal scale, comparisons among archeological sites and the occurrence of useful species in current plant communities in forests indicates that ancient human populations managed the landscapes to increase the abundance or geographical range of useful species (Levis et al. 2017; Lauterjung et al. 2018; see also Albuquerque et al. 2019a). Since some evolutionary phenomena cannot be accessed from the perspective of populations, the macroethnobiology approach may prove useful in identifying how humans have affected species evolution and biogeographical patterns.

Taken together, the three general processes incorporate several specific processes that are contingent and scale dependent. Instrumental variables (e.g., climate) are used to compare how specific processes vary under certain conditions (e.g., dry and wet seasons). However, general processes (not contingent or scale dependent) represent the drivers of variation in cultural and biological fitness (Fig. 2).

\section{How Social Negotiation Is Embedded in the Three General Processes}

Ethnobiological scholarship is increasingly concerned with the applied and societal dimensions of negotiating knowledge in complex social-ecological systems (Wyndham et al. 2011; Wolverton 2013). Rather than documenting knowledge surrounding biota and environments, ethnobiologists have turned their attention to how this knowledge becomes negotiation in practice. For the purposes of our discussion, we propose distinguishing among (1) management practices, (2) policy, and (3) political contestation as three core processes of social negotiation of ethnobiological knowledge.

Firstly, there has been increased recognition of Indigenous and local knowledge in the management of local environments. This recognition has co-evolved with wider sustainability discourse, as the influential Brundtland Report Our Common Future stated: [tribal and Indigenous] 'lifestyles can offer modern societies many lessons in the management of resources in complex forest, mountain, and dryland ecosystems' (WCED 1987: 12). Debates surrounding traditional ecological knowledge stand out as especially influential in emphasizing the knowledge of local communities in managing local ecosystems and highlighting the importance of this expertise in collaborative co-management practices (see Berkes 2010). Accordingly, the last reports of the Intergovernmental Science-Policy Platform on Biodiversity and Ecosystem Services (IPBES) have emphasized integrating social knowledge and concerns as a prerequisite for improving public policy initiatives (IPBES 2018). 
Secondly, recognition of local expertise in the management of social-ecological systems has become increasingly reflected in policy discourses. As expert-driven policy frameworks often depart from the sole recognition of Western academic expertise, ethnobiology challenges policy discourse to reflect on a variety of concerns and knowledge in constructing frameworks for management practices. Some frameworks are developed at local community or national scales (Castro and Nielsen 2001; Nursey-Bray and Rist 2009), while others aim to increase recognition of Indigenous and local knowledge at global policy scales, such as IPBES (Borie and Hulme 2015; Tengö et al. 2017).

While recognition of Indigenous and local knowledge in management practices and policy points towards more optimistic agendas of knowledge integration, ethnobiology has also become concerned with the limitations of such integration projects and the political contestation of different knowledge systems. Well-intentioned projects of knowledge integration often collide with conflicting epistemologies and ontologies as well as political realities of marginalization and oppression (Ludwig and El-Hani 2020). Rather than simply emphasizing the relevance of Indigenous and local knowledge, ethnobiology has also become increasingly concerned with environmental injustices and the political ecology of knowledge production more broadly (Wolverton et al. 2016; Fowler and Herron 2018).

Social negotiations of management practices and policies are affected by cognitive processing on different scales. Social stratification along dimensions such as gender, education lev$\mathrm{el}$, and urbanization modulate cognitive processing, which, in turn, affects social negotiation processes (Table 3). First, differences in cognitive processing are crucial for understanding management practices that often reflect division of labor in communities that interact with different practices in areas such as conservation, education, farming, hunting, and medicine (Atran et al. 2002; Villagómez Reséndiz 2017). Second, differences in cognitive processing are crucial for the design of adequate policies and transdisciplinary collaborations that are responsive to the distribution of expertise across different stakeholders (Burger et al. 2003). Third, cognitive processing also relates to political contestation as the de facto exclusion of stakeholders often contrasts with expertise that is embedded in local classifications, perceptions, and decision making. Environmental and social injustices are commonly entangled with the marginalization of Indigenous and local knowledge in the negotiation of management practices and policies (Ludwig and Macnaghten 2020).

When social negotiation is taking place, the specific process of decision making may not be evaluated only at the local level. It includes the integration of knowledge and world views among different actors to reach common purposes (e.g., natural resource conservation). Therefore, such an approach undoubtedly moves ethnobiological research from the local level to broader spatial scales. Furthermore, when local and scientific knowledge interacts, the resulting knowledge coproduction may, for example, have a vital role in adaptation to environmental change (Armitage et al. 2011).

Social negotiation is also connected to cultural transmission since it involves collective learning. Information sharing among different actors has the potential to insert novel management strategies and knowledge in a social-ecological system. In the context of environmental management, for example, there is evidence that such learning may improve governance, as it can help actors learn about each other and resolve conflicts (Biggs et al. 2012).

Finally, social negotiations may cross the generational barriers and shape, in many ways, the dynamic relationships between people and nature. For example, the province of Himachal Pradesh in the western Himalayas (India) has experienced for more than 150 years an institutional engagement between the people and the state for the control of forests in the region, which led to a series of inter-related changes in management practices and forests (Chhatre 2000). Therefore, despite the lack of information on this matter, the influence of stakeholder interactions in the dynamic inter-relations between people and nature may be a matter of interest for ethnobiology in future.

\section{Conclusion}

Social-ecological systems are inherently complex and require inter- and transdisciplinary approaches that bring together methods from heterogenous stakeholders. Ethnobiology is well-positioned to meet this challenge of complexity by combining resources from diverse disciplines, such as evolutionary biology, comparative linguistics, cognitive psychology, cultural anthropology, and political ecology. Despite this interdisciplinary potential, we argue that ethnobiology often remains fragmented through research programs that emphasize different methods and scales.

Our review addresses this problem of fragmentation by proposing a conceptual synthesis for ethnobiological studies of social-ecological systems. First, we argue that ethnobiology studies of social-ecological dynamics occur across different spatial (individual, local community, metacommunity, and macrosystem) and temporal (intra- and intergenerational) scales. Second, we distinguish between three general processes (cognitive processing, cultural transmission, and biocultural evolution) that are studied in ethnobiology and emphasized by researchers from different disciplinary backgrounds. Moreover, social negotiation is a transversal strategy affecting how the general processes determine biological and cultural fitness at different scales.

By addressing heterogeneous processes across spatial and temporal scales, the proposed framework relates factors that 
are entangled in social-ecological systems but are often studied in isolation. The integrative potential of the proposed framework is especially relevant in the context of ethnobiology 5 (Wyndham et al. 2011; Wolverton 2013) by bringing together applied questions about the negotiation of practices with basic research regarding cognitive processing, cultural transmission, and biocultural evolution. Rather than regarding applied and basic research in ethnobiology as competing for attention, our proposed framework shows how they can complement each other by increasing reflexivity about the structure of local knowledge in negotiations of issues, such as biodiversity conservation or food security.

Funding This study was financed in part by the Coordenação de Aperfeiçoamento de Pessoal de Nível Superior, Brasil (CAPES), Finance Code 001. This study benefitted from contributions of the INCT Ethnobiology, Bioprospecting, and Nature Conservation, certified by $\mathrm{CNPq}$, with financial support from FACEPE (Foundation for Support to Science and Technology of the State of Pernambuco, grant number: APQ-0562-2.01/17). ISF thanks CAPES/FACEPE (PNPD program) for providing a postdoctoral scholarship (grant numbers: APQ-0700-2.05/16 and BCT-0259.22-05/17). Thanks to $\mathrm{CNPq}$ for the productivity grant awarded to UPA. David Ludwig's research has been supported by an ERC Starting Grant (851004 LOCAL KNOWLEDGE) and a NWO Vidi Grant (V1.Vidi.195.026 ETHNOONTOLOGIES).

\section{Compliance with Ethical Standards}

Conflict of Interest The authors declare they have no conflict of interest.

Informed Consent Not applicable.

\section{References}

Albuquerque, U.P., 2006. Re-examining hypotheses concerning the use and knowledge of medicinal plants: a study in the Caatinga vegetation of NE Brazil. J. Ethnobiol. Ethnomed. 2, 30. https://doi.org/10. 1186/1746-4269-2-30

Albuquerque, U.P., de Medeiros, P.M., 2012. Systematic reviews and meta-analysis applied to ethnobiological research. Ethnobiol. Conserv. $1,1-8$.

Albuquerque, U.P., Ferreira Júnior, W.S., Santoro, F.R., Torres-Ávilez, W.M., Sousa Júnior, J.R., 2015. Niche construction theory and ethnobiology, In: Albuquerque U.P., Medeiros, P. M., Medeiros., Casas, A., Casas (Eds.), Evolutionary ethnobiology. Springer, New York, pp: 73-88.

Albuquerque, U.P., Alves, A.G.C., 2016. What is ethnobiology?, in: Albuquerque, U.P., Alves, R.R.N., (Eds.), Introduction to ethnobiology. New York: Springer pp 3-7.

Albuquerque, U.P., Ferreira Júnior, W.S., 2017. What do we study in evolutionary ethnobiology? Defining the theoretical basis for a research program. Evol. Biol. 44, 206-215. https://doi.org/10.1007/ s11692-016-9398-z

Albuquerque, U.P., Gonçalves, P.H.S., Ferreira Júnior, W.S., Chaves, L.S., Oliveira, R.C.S., Silva, T.L.L., Santos, G.C., Araújo, E.L., 2018. Humans as niche constructors: Revisiting the concept of chronic anthropogenic disturbances in ecology. Perspec. Ecol. Conserv. 16, 1-11. https://doi.org/10.1016/j.pecon.2017.08.006
Albuquerque, U.P., Nascimento, A.L.B., Silva Chaves, L., Feitosa, I.S., Moura, J.M.B., Gonçalves, P.H.S., da Silva, R.H., da Silva, T.C., Ferreira, W.S., 2019a. A brief introduction to niche construction theory for ecologists and conservationists. Biol. Conserv. 237, 50 56. https://doi.org/10.1016/j.biocon.2019.06.018

Albuquerque, U.P., Medeiros, P.M., Ferreira Júnior, W.S., et al., 2019b. Social-ecological theory of maximization: basic concepts and two initial models. Biol. Theory. 14, 73-85. https://doi.org/10.1007/ s13752-019-00316-8

Altman, A., Mesoudi, A., 2019. Understanding agriculture within the frameworks of cumulative cultural evolution, gene-culture co-evolution, and cultural niche construction. Human Ecol. 47, 483-497. https://doi.org/10.1007/s10745-019-00090-y

Amahowe, I.O., Gaoue O.G., Natta, A.K., Piponiot, C., Zobi, I.C., Hérault, 2018. Functional traits partially mediate the effects of chronic anthropogenic disturbance on the growth of a tropical tree. AoB Plants. 10, 1-13. https://doi.org/10.1093/aobpla/ply036

Armitage D., Berkes, F., Dale, A., Kocho-Schellenberg, E., Patton, E., 2011. Co-management and the co-production of knowledge: Learning to adapt in Canada's Arctic. Glob. Environ. Chang. 21, 995-1004.

Ávila, J.V.C., Mello, A.S., Berreta, M.E., Trevisan, R., Fiaschi, P., Hanazaki, N., 2017. Agrobiodiversity and in situ conservation in quilombola home gardens with different intensities. Acta Bot. Bras. 31, 1. https://doi.org/10.1590/0102-33062016abb0299

Atran, S., Medin, D., Ross, N., Lynch, E., Vapnarsky, V., Ek, E., et al., 2002. Folkecology, cultural epidemiology, and the spirit of the commons: a garden experiment in the Maya lowlands, 19912001. Curr. Anthropol. 43, 421-450.

Ayantunde, A.A., Briejer, M., Hiernaux, P., Udo, H.M.J., Tabo, R., 2008. Botanical knowledge and its differentiation by age, gender and ethnicity in southwestern Niger. Hum. Ecol. 36, 881-889.

Barrett, H.C., Broesch, J., 2012. Prepared social learning about dangerous animals in children. Evol. Hum. Behav. 33, 499-508. https://doi. org/10.1016/j.evolhumbehav.2012.01.003

Bellon, M.R., 2014. The ethnoecology of maize variety management: A case study from Mexico. Hum. Ecol. 19, 389-418.

Bender, M.G., Machado, G.R., Silva, P.J.A., Floeter, S.R., MonteiroNeto, C., Luiz, O.J., Ferreira, C.E.L., 2014. Local ecological knowledge and scientific data reveal overexploitation by multigear artisanal fisheries in the Southwestern Atlantic. PLoS ONE 9, e110332. https://doi.org/10.1371/journal.pone.0110332

Berlin, B., 1992. Ethnobiological classification: principles of categorization of plants and animals in traditional societies. Princeton University Press, Princeton.

Berkes, F., 2010. Linkages and multilevel systems for matching governance and ecology: Lessons from roving bandits. Bull. Mar. Sci. 86, $235-250$.

Biggs, R., Schluter, M., Biggs, D., Bohensky, E.L., BurnSilver, S., Cundill, G., Dakos, V., Daw, T.M., Evans, L.S., Kotschy, K., Leitch, A.M., Meek, C., Quinlan, A., Raudsepp-Hearne, C., Robards, M.D., Schoon, M.L., Schultz, L., West, P.C., 2012. Toward principles for enhancing the resilience of ecosystem services. Annu. Rev. Env. Resour. 37, eds. A. Gadgil and D. M. Liverman.

Borie M, Hulme M, 2015. Framing global biodiversity: IPBES between mother earth and ecosystem services. Environ. Sci. Policy. 54, 487496. https://doi.org/10.1016/j.envsci.2015.05.009.

Boyd, R., Richerson, P.J., 2005. The origins, evolution of human culture. Oxford: Oxford University Press.

Braga, H.O., Pereira, M.J., Morgado, F. et al. 2019. Ethnozoological knowledge of traditional fishing villages about the anadromous sea lamprey (Petromyzon marinus) in the Minho river, Portugal. J Ethnobiology Ethnomedicine 15, 71. https://doi.org/10.1186/ s13002-019-0345-9 
Brito, C.C., Silva, T.C., Albuquerque, U.P., Ramos, M.A., Ferreira Júnior, W.S., Barros, F.N., Costa Neto, E.M., Medeiros, P.M., 2017. The use of different indicators for interpreting the local knowledge loss on medical plants. Rev. Bras. Farmacogn. 27, 245-250. http://www.sciencedirect.com/science/article/pii/ S0102695X16300369

Brito, C.C., Ferreira Júnior, W.S., Albuquerque, U.P., Ramos, M.A., Silva, T.C., Costa-Neto, E.M., Patrícia Medeiros, P.M., 2019. The role of kinship in knowledge about medicinal plants: evidence for context-dependent model-based biases in cultural transmission? Acta Bot. Bras. https://doi.org/10.1590/0102-33062018abb0340

Bufford, J.L., Gaoue, O.G., 2015. Defoliation by pastoralists affects savanna tree seedling dynamics by limiting the facilitative role of canopy cover. Ecol. Appl. 25, 1319-1329. https://doi.org/10.1890/ 14-0953.1

Burger, P., Kamber, R., 2003. Cognitive integration in transdisciplinary science. Issues in Integrative Studies, 21, 43-73.

Cavalli-Sforza, L.L., Feldman, M., 1981. Cultural transmission, evolution: a quantitative approach. 1st ed. Princeton: Princeton University Press.

Chen, I., Kondoh, C.H., Lin, H., Nakamura, T.M., Ohgushi, T., Yoshida, J.U., 2017. Filling the gaps in ecological studies of socioecological systems. Ecol. Res. 32, 873-885. https://doi.org/10.1007/s11284017-1521-9

Chhatre, A. 2000. Forest co-management as if history mattered-the case ofwestern Himalayan forests in India. International Association for the Study of Common Property Conference, 2000, Bloomington, Indiana.

Castro, A. P., Nielsen, E. (2001). Indigenous people and co-management: implications for conflict management. Environ. Sci. Policy. 4, 229 239.

Dantas, J.I., Nascimento, A.L.B., Silva, T.C., Albuquerque, U.P. 2020. Mutation of cultural information on the use of plant complexes in local medical systems. Evid. Based Complementary Altern. Med. 2020, 1-11. https://doi.org/10.1155/2020/7630434

Díaz-Reviriego, I., Fernández-Llamazares, A., Salpeteur, M., Howard, P.L., Reyes-García, V., 2016. Gendered medicinal plant knowledge contributions to adaptive capacity and health sovereignty in Amazonia. Ambio 45, S263-S275. https://doi.org/10.1007/ s13280-016-0826-1

Eriksson, K., Coultas, J.C., 2014. Corpses, maggots, poodles and rats: emotional selection operating in three phases of cultural transmission of urban legends. J. Cog. Cult. 14, 1-26. https://doi.org/10. 1163/15685373-12342107

Eyssartier, C., Ladio, A.H., Lozada, M., 2008. Cultural transmission of traditional knowledge in two populations of North-Western Patagonia. J. Ethnobiol. Ethnomed. 4, 25. https://doi.org/10.1186/ 1746-4269-4-25

Fedele, G., Donatti, C.I., Harvey, C.A., Hannah, L., Hole, D.G., 2019. Transformative adaptation to climate change for sustainable socialecological systems. Environ. Sci. Policy. 101, 116-125. https://doi. org/10.1016/j.envsci.2019.07.001

Feitosa, I.S., Sobral, A., Monteiro, J.M., Araújo, E.L., Albuquerque, U.P., 2017. Impact of collection on bark regeneration from Stryphnodendron rotundifolium Mart. in northeastern Brazil. Environ. Monit. Assessm. 189: 1-11. https://doi.org/10.1007/ s10661-017-5908-4

Fernández-Llamazares, A., Díaz-Reviriego, I., Luz, A.C., Cabeza, M., Pyhälä, A., Reyes-García, V., 2015. Rapid ecosystem change challenges the adaptive capacity of local environmental knowledge. Glob. Environ. Change. 31, 272-284. https://doi.org/10.1016/j. gloenvcha.2015.02.001

Fowler, C., \& Herron, S. (2018). The Long Program for Ethics in Ethnobiology. Ethnobiology Letters, 9(1), 1-3. Retrieved October 15, 2020, from https://www.jstor.org/stable/26455336
Gaoue, O.G., Horvitz, C.C., Steiner, U.K., Tuljapurkar, S., 2019. Climate, rather than human disturbance, is the main driver of agespecific mortality trajectories in a tropical tree. Ecol. Model. 400, 34-40. https://doi.org/10.1016/j.ecolmodel.2019.03.007

Giovannini, P., Reyes-García, V., Waldstein, A., Heinrich, M., 2011. Do pharmaceuticals displace local knowledge and use of medicinal plants? Estimates from a cross-sectional study in a rural indigenous community, Mexico. Soc. Sci. Med. 72, 928-936. https://doi.org/ 10.1016/j.socscimed.2011.01.007

Gonçalves, P.H.S., Albuquerque, U.P., Medeiros, P.M., 2016. The most commonly available woody plant species are the most useful for human populations: A meta-analysis. Ecol. Appl. 26, 2238-2256. https://doi.org/10.1002/eap.1364

Gonçalves, P.H.S., Rego, A.E.M., Medeiros, P.M., 2019. There was a virgin forest here; it was all woods: local perceptions of landscape changes in Northeastern Brazil. Ethnobiol. Conserv. 8, 4.

Guinand, Y., Lemessa, D. 2001. Wild-food plants in Ethiopia: Reflections on the role of "wild-foods" and "famine-foods" at the time of drought, eds. C. Kenyatta and A. Henderson, USAID/ OFDA, CRS/Southern Sudan, p. 31-46.

Gutiérrez-Santillán, T.V., Valenzuela-Galván, D., Albuquerque, U.P., Reyes-Zepeda, F., Arellano-Méndez, L.U., Mora-Olivo, A., Vásquez, L. 2019. The spatiotemporal scale of ethnobiology: A conceptual contribution in the application of meta-analysis and the development of the macro-ethnobiological approach. In: Albuquerque, U.P., Lucena, R.F.P., Cunha, L.V.F.C., Alves, R.R.N. (Eds.), Methods and Techniques in Ethnobiology and Ethnoecology, Springer, New York, pp. 127-147.

Haloin, J.R., Strauss, S.Y., 2008. Interplay between ecological communities and evolution. Review of feedbacks from microevolutionary to macroevolutionary scales. Ann. N.Y. Acad. Sci. 1133, 87-125. https://doi.org/10.1196/annals.1438.003

Hanazaki, N., Herbst, D.F., Marques, M.S., Vandebroek, I., 2013. Evidence of the shifting baseline syndrome in ethnobotanical research. J. Ethnobiol. Ethnomed. 9, 75. http://www.ethnobiomed. com/content $/ 9 / 1 / 75$

Hanazaki, N., Tamashiro, J.Y., Leitão Filho, H.F., Begossi, A. 2000. diversity of plant uses in two Caiçara communities from the Atlantic forest coast, Brazil. Biodivers. Conserv. 9, 597-615. https://doi.org/10.1023/A:1008920301824

Hart, G., Gaoue, O.G., de la Torre, L., Navarrete, H., Muriel, P., Macía, M.J., Balslev, H., León-Yánez, S., Jørgensen, P., Duffy, D.C., 2017. Availability, diversification and versatility explain human selection of introduced plants in Ecuadorian traditional medicine. PLoS One 12, e0184369. https://doi.org/10.1371/journal.pone.0184369

Henrich, J., Henrich, N., 2010. The evolution of cultural adaptations: Fijian food taboos protect against dangerous marine toxins. Proc. R. Soc. B. 277, 3715-3724. https://doi.org/10.1098/rspb.2010.1191

Heath, C., Bell, C., Sternbeig, E., 2001. Emotional selection in mêmes: The case of urban legends. J. Pers. Soc. Psychol. 81, 1028-1041. https://doi.org/10.1037//0022-3514.81.6.1028

Hunn, E., 2007. Ethnobiology in four phases. J. Ethnobiol. 27, 1-10.

IPBES. (2018). The IPBES regional assessment report on biodiversity and ecosystem services for the Americas. Rice, J., Seixas, C.S., Zaccagnini, M.E., Bedoya-Gaitán, M., and Valderrama, N. (eds.). Secretariat of the Intergovernmental Science-Policy Platform on Biodiversity and Ecosystem Services, Bonn, Germany, 656 pages.

Johnson MT, Stinchcombe JR. 2007. An emerging synthesis between community ecology and evolutionary biology. Trends Ecol Evol. 22(5):250-257. https://doi.org/10.1016/j.tree.2007.01.014.

Koster, J., Bruno, O., Burns, J.L., 2016. Wisdom of the elders? ethnobiological knowledge across the lifespan. Curr. Anthropol. 57, 113121.

Kujawska, M., Łuczaj, Ł., 2015. Wild edible plants used by the Polish community in Misiones, Argentina. Human Ecol. 43, 855-869. https://doi.org/10.1007/s10745-015-9790-9 
Ladio, A.H., Lozada, M., (2008). Medicinal plant knowledge in rural communities of North-Western Patagonia, Argentina. A resilient practice beyond acculturation. In: Albuquerque, U.P., Ramos, M.A. (eds) Current topics in Ethnobotany. Research Signpost, 3953.

Laland, K.N., Brown, G.R., 2006. Niche construction, human behavior, and the adaptive-lag hypothesis. Evol. Anthropol. 15, 95-104. https://doi.org/10.1002/evan.20093

Lauterjung, M.B., Bernardi, A.P., Montagna, T., Candido-Ribeiro, R., da Costa, N.C.F., Mantovani, A., dos Reis, M.S., 2018. Phylogeography of Brazilian pine (Araucaria angustifolia): Integrative evidence for pre-Columbian anthropogenic dispersal. Tree Genet. Genomes. 14. https://doi.org/10.1007/s11295-018$1250-4$

Levis, C., Costa, F.R.C., Bongers, F., Peña-Claros, M., Clement, C.R., Junqueira, A.B. et al., 2017. Persistent effects of pre-Columbian plant domestication on Amazonian forest composition. Sci. 355, 925-931. https://doi.org/10.1126/science.aal0157

Linstädter, A., Kemmerling, B., Baumann, G., Kirscht, H., 2013. The importance of being reliable - Local ecological knowledge and management of forage plants in a dryland pastoral system (Morocco). J. Arid Environ. 95, 30-40. https://doi.org/10.1016/j. jaridenv.2013.03.008

López, A., Atran, S., Coley, J.D., Medin, D.L., Smith, E.E., 1997. The tree of life: universal and cultural features of folkbiology taxonomies and inductions. Cogn. Psychol. 32, 251-295. https://doi.org/10. 1006/cogp.1997.0651

Ludwig, D., 2018. Does cognition still matter in ethnobiology? Ethnobiol. Letters. 9, 269-275. https://doi.org/10.14237/ebl.9.2. 2018.1350

Ludwig, D., El-Hani, C., 2020. Philosophy of ethnobiology: understanding knowledge integration and its limitations. J. Ethnobiol. 40(1), 320.

Ludwig, D., Macnaghten, P., 2020. Traditional ecological knowledge in innovation governance: A framework for responsible and just innovation. J. Respons. Innov. 7, 26-44.

Maua, K.J., Tsingalia O., Harrison M., Cheboiwo, J., (2018). Socioeconomic factors influencing dependence of households on non-timber forest products in South Nandi Forest. JEDS 9, 14.

McGraw, J.B., 2001. Evidence for decline in stature of American ginseng plants from herbarium specimens. Biol. Conserv. 98, 25-32. https:// doi.org/10.1016/S0006-3207(00)00138-5

Mesoudi, A., 2015. Cultural Evolution: A review of theory, findings and controversies. Evol. Biol. 43, 481-497. https://doi.org/10.1007/ s11692-015-9320-0

Mesoudi A., 2016. Cultural evolution: Integrating psychology, evolution and culture. Curr. Opi. Psychol. 7, 17-22. https://doi.org/10.1016/j. copsyc.2015.07.001

Mesoudi, A., Whiten, A., Lal, K., 2006. Towards a unified science of cultural evolution. J. Behav. Brain Sci. 29, 329-383. https://doi.org/ 10.1017/S0140525X06009083

Medeiros, P.M., Almeida, A.L.S., Silva, T.C., Albuquerque, U.P. 2011. Pressure indicators of wood resource use in an Atlantic Forest area, northeastern Brazil. Environ. Manage. 47, 410-424. https://doi.org/ 10.1007/s00267-011-9618-3

Medeiros, P.M., Ladio, A.H., Santos, A.M.M., Albuquerque, U.P., 2013. Does the selection of medicinal plants by Brazilian local populations suffer taxonomic influence? J. Ethnopharmacol. 146, 842-852. https://doi.org/10.1016/j.jep.2013.02.013

Medeiros, P.M., Soldati, G.T., Alencar, N., Vandebroek, I., Pieroni, A., Hanazaki, N., Albuquerque., U.P., 2012. The use of medicinal plants by migrant people: Adaptation, maintenance, and replacement. ECAM. https://doi.org/10.1155/2012/807452

Milla, R., Bastida, J.M., Turcotte, M.M., et al., 2018. Phylogenetic patterns and phenotypic profiles of the species of plants and mammals farmed for food. Nat. Ecol. Evol. 2, 1808-1817. https://doi.org/10. 1038/s41559-018-0690-4

Miranda, T.M., Hanazaki, N., 2008. Conhecimento e uso de recursos vegetais de restinga por comunidades das ilhas do Cardoso (SP) e de Santa Catarina (SC), Brasil. Acta Bot. Bras., 22, 203-215.https:// doi.org/10.1590/S0102-33062008000100020

Moerman, D.E., 1979. Symbols and selectivity: A statistical analysis of Native American medical ethnobotany. J. Ethnopharmacol. 1, 111119. https://doi.org/10.1016/0378-8741(79)90002-3

Moerman, D.E., 1991. The medicinal flora of native North America: An analysis. J. Ethnopharmacol. 31, 1-42. https://doi.org/10.1016/ 0378-8741(91)90141-Y

Monteiro, J.M., Lins Neto, E.M.F., Araújo, E.L., Amorim, E.L.C., Albuquerque, U.P., 2011. Bark regeneration and tannin content in Myracrodruon Urundeuva Allemão after simulation of extractive damages-implications to management. Environ. Monit. Assess. 180, 31-39. https://doi.org/10.1007/s10661-010-1770-3

Moura, J.M.B., Silva, R.H., Ferreira Júnior, W.S., Silva, T.C., Albuquerque, U.P., 2020. Theoretical insights of evolutionary psychology: New opportunities for studies in evolutionary ethnobiology. Evol Biol 47: https://doi.org/10.1007/s1 1692-020-09491-0

Nabhan, G. P., ed. 2016. Ethnobiology for the Future: Linking Cultural and Ecological Diversity. Tucson: University of Arizona Press.

Nairne, J.S., Thompson, S.R., Pandeirada, J.N.S., 2007. Adaptive memory: Survival processing enhances retention. J. Exp. Psychol. 33, 263-273. https://doi.org/10.1037/0278-7393.33.2.263

Nairne, J.S., Pandeirada, J.N.S., 2008. Adaptive memory: Is survival processing special? J. Mem. Lang. 59, 377-385. https://doi.org/10. 1016/j.jml.2008.06.001

Nascimento, V.T., Vasconcelos, M.A.S., Maciel, M.I.S., Albuquerque, U.P., 2012. Famine foods of Brazil's seasonal dry forests: Ethnobotanical and nutritional aspects. Econ. Bot. 66, 22-34.

Nascimento, A.L.B., Medeiros, P.M., Albuquerque, U.P., 2018. Factors in hybridization of local medical systems: Simultaneous use of medicinal plants and modern medicine in Northeast Brazil. PLoS One. 13, e0206190. https://doi.org/10.1371/journal.pone.0206190

N'Danikou, S., Achigan-Dako, E.G., Tchokponhoue, D.A., Agossou, C.O.A., Houdegbe, C.A., Vodouhe, R.S., Ahanchede, A., 2015. Modelling socioeconomic determinants for cultivation and in-situ conservation of Vitex doniana Sweet (Black plum), a wild harvested economic plant in Benin.J. Ethnobiol. and Ethnom. 11, 28. https:// doi.org/10.1186/s13002-015-0017-3

Nursey-Bray, M., Rist, P., 2009. Co-management and protected area management. Mar. Policy 33, 118-127.

Paniagua-Zambrana, N.Y., Camara-Lerét R., Bussmann, R.W., Macía, M.J., 2014. The influence of socioeconomic factors on traditional knowledge: A cross scale comparison of palm use in northwestern South America. Ecol. Soc. 19, 9. https://doi.org/10.5751/ES-06934190409

Poderoso, R.A., Peroni N., Hanazaki, N., 2017. Gender influences in the perception and use of the landscape in a rural community of German immigrant descendants in Brazil. J. Ethnobiol. 37, 779-797. https:// doi.org/10.2993/0278-0771-37.4.779

Pincetl, S., 2017. Cities in the age of the Anthropocene: Climate change agents and the potential for mitigation. Anthropocene 20,74-82. https://doi.org/10.1016/j.ancene.2017.08.001

Rangel-landa, S., Casas, A., Rivera-Lozoya, E., Torres-García, I., Vallejo-Ramos, M., 2016. Ixcatec ethnoecology: Plant management and biocultural heritage in Oaxaca, Mexico. J. Ethnobiol. Ethnomed. 12, 30. https://doi.org/10.1186/s13002-016-0101-3

Rao, M., Htun, S., Zaw, T., Myint, T., 2010. Hunting, livelihoods and declining wildlife in the Hponkanrazi Wildlife Sanctuary, North Myanmar. Environ. Manage. 46, 143-153. https://doi.org/10.1007/ s00267-010-9519-x

Reyes-García, V., Vadez, V., Byron, E., Apaza, L., Leonard, W.R., Perez, E., Wilkie, D., 2005. Market economy and the loss of folk 
knowledge of plant uses: Estimates from the Tsimane' of the Bolivian Amazon. Curr. Anthropol. 46, 651-656.

Reyes-García, V., Broesch, J., Calvet-Mir, L., Fuentes-Peláez, N., McDade, T.W., Parsa, S., Tanner, S., Huanca, T., Leonard, W. R., Martínez-Rodríguez, M.R., 2009. Cultural transmission of ethnobotanical knowledge and skills: an empirical analysis from an Amerindian society. Evol. Hum. Behav. 30, 274-285. https://doi. org/10.1016/j.evolhumbehav.2009.02.001

Reyes-García, V., Guèze, M., Luz, A.C., Paneque-Gálvez, J., Macía, M.J., Orta-Martínez, M., Pino, J., Rubio-Campillo, X., 2013. Evidence of traditional knowledge loss among a contemporary indigenous society. Evol. Hum. Behav. 34, 249-257. https://doi.org/ 10.1016/j.evolhumbehav.2013.03.002

Reyes-Garcia, V., Vila S., Aceituno-Mata, L., Calvet-Mir, L., Garnatje, T., Jesch, A., Lastra, J.J., Parada, M., Rigat, M., Vallès, J., PardodeSantayana, M., 2010. Gendered home gardens: A study in three mountain areas of the Iberian Peninsula. Econ. Bot. 64, 235-247.

Roy, K., Valentine, J.W., Jablonski, D., Kidwell, S.M., 1996. Scales of climatic variability and time averaging in Pleistocene biotas: Implications for ecology and evolution. Tree 11, 458-463. https:// doi.org/10.1016/0169-5347(96)10054-9

Ruddle, K., 2000. Systems of knowledge: Dialogue, relationships and process. Environ. Develop. Sustain. 2, 277-304. https://doi.org/10. 1023/A:1011470209408

Saslis-Lagoudakis, C.H., Savolainen, V., Williamson, E.M., Forest, F., Wagstaff, S.J., Baral, S.R., Watson, M.F., Pendry, C.A., Hawkins, J.A., 2012. Phylogenies reveal predictive power of traditional medicine in bioprospecting. Proc. Natl. Acad. Sci. U.S.A. 109, 1583515840. https://doi.org/10.1073/pnas.1202242109

Saslis-Lagoudakis, C.H., Williamson, E.M., Savolainen, V., Hawkins, J.A., 2011. Cross-cultural comparison of three medicinal floras and implications for bioprospecting strategies. J. Ethnopharmacol. 135, 476-487. https://doi.org/10.1016/j.jep.2011.03.044

Santoro, F.R., Santos, G.C., Ferreira Júnior, W.S., Chaves, L.S., Araújo, T.A.S., Nascimento, A.L.B., Sobral, A., Silva, J.S., Campos, J.L.A., Albuquerque, U.P., 2017. Testing an ethnobiological evolutionary hypothesis on plant-based remedies to treat malaria in Africa. Evol. Biol. 44, 216-226. https://doi.org/10.1007/s11692-016-9400-9

Santoro, F.R., Santos, G.C., Ferreira Júnior, W.S., Chaves, L.S., Araújo, T.A.S., Nascimento, A.L.B., Sobral, A., Silva, J.S., Campos, J.L.A., Albuquerque, U.P., 2017. Testing an ethnobiological evolutionary hypothesis on plant-based remedies to treat malaria in Africa. Evol. Biol. 44, 216-226. https://doi.org/10.1007/s11692-016-9400-9

Santoro, F.R., Nascimento, A.L.B., Soldati, G.T., Ferreira Júnior, W.S., Albuquerque, U.P., 2018. Evolutionary ethnobiology and cultural evolution: opportunities for research and dialog. J. Ethnobiol. Ethnomed. 14, 1-14. https://doi.org/10.1186/s13002-017-0199

Santoro, F.R., Chaves, L.S., Albuquerque, U.P., 2020. Evolutionary aspects that guide the cultural transmission pathways in a local medical system in Northeast Brazil. Heliyon 6, e04109 https://doi.org/ 10.1016/j.heliyon.2020.e04109

Salpeteur, M., Patel, H., Balbo, A., Rubio-Campillo, X., Madella, M., Ajithprasad, P., Victoria Reyes-García, V., 2015. When knowledge follows blood: Kin groups and the distribution of traditional ecological knowledge in a community of Seminomadic Pastoralists, Gujarat (India). Curr. Anthropol. 56, 471-483. https://doi.org/10. 1086/681006ff.ffhalshs-01973769f

Silva, T.C., Medeiros, M.F.T., Peroni, N., Albuquerque, U.P., 2016. Folk classification as evidence of transformed landscapes and adaptative strategies: A case study in the semiarid region of northeastern Brazil. Land. Res. 42, 521-532. https://doi.org/10.1080/01426397.2016. 1258047

Silva, T.C., Campos, L.Z.O., Balée, W., 2017. Human impact on the abundance of useful species in a protected area of the Brazilian Cerrado by people perception and biological data. Land. Res. 43, 1-14. https://doi.org/10.1080/01426397.2017.1396304
Soldati, G.T., Hanazaki, N., Sieves, M., Albuquerque, U.P., 2015. Does environmental instability favor the production and horizontal transmission of knowledge regarding medicinal plants? A study in Southeast Brazil. PLoS ONE 10, e0126389. https://doi.org/10. 1371/journal.pone.0126389

Spainer, E., Lavalli, K., 2007. Slipper lobster fisheries: Present status and future perspectives, in: Lavalli, K.L., Spainer, E. (Eds.), The biology and fisheries of the slipper lobster. CRC Press, Florida, pp: 325-358.

Spalding, P., 2020. Partnerships of hope: How ethnoecology can support robust co-management agreements between public governments and Indigenous peoples. In: Plants, People, and Places: The Roles of Ethnobotany and Ethnoecology in Indigenous Peoples' Land Rights in Canada and Beyond 96, 366.

Souza, E.N.F., Williamson, E.M., Hawkins, J.A., 2018. Which plants used in ethnomedicine are characterized? Phylogenetic patterns in traditional use related to research effort. Front. Plant. Sci. 9,12. https://doi.org/10.3389/fpls.2018.00834

Tangjitman, K., Wongsawad, C., Winijchaiyanan, P., 2013. Traditional knowledge on medicinal plant of the Karen in northern Thailand: A comparative study. J. Ethnopharmacol. 150, 232-243. https://doi. org/10.1016/j.jep.2013.08.037

Tengö, M., Hill, R., Malmer, P., Raymond, C.M., Spierenburg, M., Danielsen, F., et al., 2017. Weaving knowledge systems in IPBES, $\mathrm{CBD}$ and beyond-lessons learned for sustainability. Curr. Opin. Environ. Sustainability. 26, 17-25.

Torres-Avilez, W., Medeiros, P.M., Albuquerque, U.P. 2016. Effect of gender on the knowledge of medicinal plants: systematic review and meta-analysis. ECAM 2016. https://doi.org/10.1155/2016/6592363.

Vandebroek, I., Calewaert, J., De Jonckheere, S., Sanca, S., Semo, L., van Damme, P., Puyvelde, L.V., Kimpe, N., 2004. Use of medicinal plants and pharmaceuticals by Indigenous communities in the Bolivian Andes and Amazon. Bull. World Health Organ. 82, 243-250.

Vellend, M. 2010. Conceptual Synthesis in Community Ecology. The Quarterly Review of Biology, 85(2), 183-206. https://doi.org/10. 1086/652373.

Villagómez Reséndiz, R., 2017. "Hacia una Etnobiología Cognitiva: Tecnología Hidráulica Mesoamericana y Cognición en los Altos de Morelos." Etnobiol. 15, 89-98.

Vellend, M. 2020. The theory of ecological communities. Princeton; Oxford: Princeton University Press. 2016. 229.

Waring, T.M., Kline, M.A., Brooks, J.S., Goff, S.H., Gowdy, J., Jassen, M.A., Smaldino, P.E., Jacquet, J., 2015. A multilevel evolutionary framework for sustainability analysis. Ecol. Soc. 20, 34. https://doi. org/10.5751/ES-07634-200234

WCED. World Comission on Environment and Development 1987. Our Commom Future. Oxford and New York: Oxford University Press, 1987.

Weckerle, C.S., Cabras, S., Castellanos, M.E., Leonti, M., 2011. Quantitative methods in ethnobotany and ethnopharmacology: Considering the overall flora - Hypothesis testing for over- and underused plant families with the Bayesian approach. J. Ethnopharmacol. 137, 837-843. https://doi.org/10.1016/j.jep.2011.07.002

Wolverton, S., Nolan, J.M., Fry, M., 2016. Political ecology and ethnobiology. In Introduction to Ethnobiology (pp. 75-82). Cham: Springer.

Wyndham, F.S., Lepofsky, D., Tiffany, S., 2011. Taking stock in ethnobiology: Where do we come from? What are we? Where are we going? J. Ethnobiol. 31, 110-127.

Wolverton, S. 2013. Ethnobiology 5: Interdisciplinarity in an Era of Rapid Environmental Change. Ethnobiology Letters 4:21-25.

Publisher's Note Springer Nature remains neutral with regard to jurisdictional claims in published maps and institutional affiliations. 